\title{
Exploring A Teacher Educator's Experiences in Modeling TPACK to Create English Language Multimedia in Technology Courses
}

\author{
Iwan Setiawan \\ Universitas Negeri Makassar, Jln. Bonto Langkasa, Kampus Gunung Sari, Makassar, South Sulawesi, Indonesia \\ Ariffudin Hamra \\ Universitas Negeri Makassar, Jln. Bonto Langkasa, Kampus Gunung Sari, Makassar, South Sulawesi, Indonesia \\ Baso Jabu \\ Universitas Negeri Makassar, Jln. Bonto Langkasa, Kampus Gunung Sari, Makassar, South Sulawesi, Indonesia \\ Susilo \\ Universitas Negeri Makassar, Jln. Bonto Langkasa, Kampus Gunung Sari, Makassar, South Sulawesi, Indonesia
}

\begin{abstract}
TPACK framework as an established term for describing what teachers need to know to integrate technology effectively into their teaching practices has been widely addressed by teachers and teacher educators and it has been a flourishing field of investigation. However, teacher educators' model in the context of using varieties of software in exploiting the benefits of technology by looking at how the framework could be implemented is restricted. Therefore the aim of this study is to explore a teacher educator's experiences in modelling his teaching and learning based on the TPACK framework using qualitative research into biographical case study narrative. Two data collection techniques (i.e; interview and observation) were used to support the data collection process. The findings of this study suggest that it is important for teacher educators to incorporate Project Based Learning in TPACK and to combine varieties of software for creating English language multimedia as it could develop both teacher educator's and pre-service teachers' knowledge on content, technology, and pedagogy and their intersections. Furthermore, the use of blended learning would allow pre-service teachers to directly see, learn, observe, and experience how to learn and how to teach English using technology.
\end{abstract}

Index Terms - technology integration, multimedia learning, TPACK framework

\section{INTRODUCTION}

It is widely known that teaching and learning are considered complex processes. The focus is not only on what knowledge of a subject should be known or acquired by learners but also on how the knowledge would be transmitted in the classroom by the teachers. Moreover, this would involve the teachers' decision of what to do in the classroom to achieve the desired goal of teaching and learning. The demands on teachers' knowledge nowadays is not only centered on knowledge of the content they are teaching, their general pedagogical knowledge with special reference to principles and strategies in the classroom, and pedagogical content knowledge, but they are also expected to conduct effective teaching with technology. In the field of language teaching and learning, this development is marked by important changes in the history of computer-assisted language learning (CALL). Warschauer and Healey (1998) divide this development into three stages called Behaviouristic CALL, Communicative CALL, and Integrative CALL. At the first stage, Behaviouristic CALL is considered a sub-component of computer-assisted instruction implemented in the 1960s and 1970s which functioned as a mechanical tutor to perform repetitive language drills, referred to as drill-and-practice which allowed students to work at an individual pace. In the late 1970s and early 1980s, Communicative CALL emerged and stressed that learning was a process of discovery, expression, and development. The next stage has been termed Integrative CALL which led to attempts to integrate various skills and technology into language learning processes which encourage students to learn to use various technological tools as an ongoing process of language learning and use.

Apart from a critical examination and reassessment of the history of CALL, and argument for three new categoriesRestricted, Open and Integrated CALL (Bax, 2003), this long history on the use of technology is an indication that integrating technology is not an easy thing for teachers to do. Therefore, teacher education programs should prepare their pre-service teachers or prospective teachers to get acquainted with technology and integrate it into their future teaching. This view is supported by Goktas, Yildirim, and Yildirim (2008), who claim that teacher educators are responsible for introducing Information and Communication Technology (ICT) to prospective teachers in dedicated ICT 
courses, and that pre-service teachers gain much-needed skills and develop positive attitudes toward ICT usage during these courses.

However, observation of classroom teachers and pre-service teachers who did grow up with much of the modern classroom technologies suggests that they may know how to use these technologies, but may not yet have learned how to implement them into the classroom productively or how to use them to enhance instruction (Rice, Johnson, Ezzel, Pierczynski, 2008). In this vein, technology courses within the teacher preparation program should be handled by "an instructor familiar with technology and pedagogy who teaches the course". The presence of experienced teacher educators who know that one form of technology does not always work best for all students in a classroom would be decisive for the knowledge development of pre-service teachers in embracing technology for their future teaching (Rice, Johnson, Ezzel, Pierczynski, 2008). In other words, language teacher education should choose lecturers or teacher educators who have the capability to integrate a wide range of technology tools and to model teaching and learning process using technology. Teacher educators' expertise in manipulating and making use of various types of technology tools in their teaching experiences could benefit others who are interested in the field of teaching using technology not only in technology courses but also in other courses offered in a language teacher education. Besides having the ability in making use of technology, teacher educators should have a well-built type of framework to follow that will guide how technology is effectively integrated into teaching. The TPACK framework, as an established term for describing what teachers need to know to integrate technology effectively into their teaching practices, has been widely addressed by teachers and teacher educators and it has been a flourishing field of investigation. However, a systematic review of TPACK by Chai, Koh, and Tsai (2013) identified issues, trends, and findings that demonstrated that TPACK framework research still needs to be developed to guide possible areas for future research and that TPACK needs to be further understood and developed into an actionable framework that can guide teachers' design of ICT interventions.

This current study is intended to explore a teacher educator's experiences in modeling the TPACK framework to create English language multimedia in technology courses offered in the English Department of the Faculty of Teacher Training and Education at Mulawarman University. Specifically, it aims to answer the question, "How does the teacher educator model his teaching and learning based on the TPACK framework?"

\section{A. Technology Integration}

There is a shared belief that technology as a facilitating tool would benefit both teachers and students. There are at least three broad benefits of incorporating technology into classroom work. They are cognitive gain from the effect of the visualization process that accompanies software; motivational gain as students can have more fun than ordinary learning; and interactional gain as the most powerful aspect of the software lies in its potential for bringing about a shift in the working relations between students and teachers (Davies, 2007).

Technology integration is not limited to just having physical pieces of equipment in the classroom (Rice, Johnson, Ezzel, Pierczynski, 2008). They further remark that having the equipment but not knowing how to use it productively does not accurately address the requirements for technology integration. Related to this idea, Renders (2009) points out that the ability to incorporate and integrate technology into teaching depends on the teacher's level of technological expertise. This could involve being able to use a certain technology, being able to create materials and activities using that technology, and being able to teach with technology. It means that technology integration depends on the ability of teachers to use various technological tools, including software, for teaching.

For technology courses, Morrison and Lowther (2010) list five categories of software that should be integrated. They are, first, productivity software (word processing, spread-sheets, presentation software, databases, graphic organizers, graphic software, digital audio editing, digital video editing, and multimedia authoring software); second, research software (browsers, search engines, and plug-ins); third, both asynchronous digital communication software (electronic mail, lists, discussion boards, blogs, Wiki, and podcast) and synchronous digital communication software (chat, instant messaging); fourth, problem-solving software (games, and simulations); and fifth, educational software (drill and practice, tutorials, integrated learning systems or ILS, process tools).

\section{B. Multimedia Learning}

Multimedia learning is learning from words and picture with an assumption that people can learn more deeply from words and pictures than from words alone while multimedia itself is defined as presenting both words which are presented in verbal form (such as spoken text or printed text) and pictures which are presented in pictorial form (such as illustrations, photos, animation, or video) that are intended to promote learning (Mayer, 2016). He then argues that in learning, the human mind works as a dual-channel, limited-capacity, and active processing system, as opposed to some other theories of multimedia communication that claim that learning is a single-channel, unlimited capacity, and passive process activity. An understanding of how the human mind works would greatly influence the making of multimedia in such a way as to deliver the intended messages of multimedia designers. The feature of how the human mind works known as cognitive theory of multimedia is shown in the following table. 


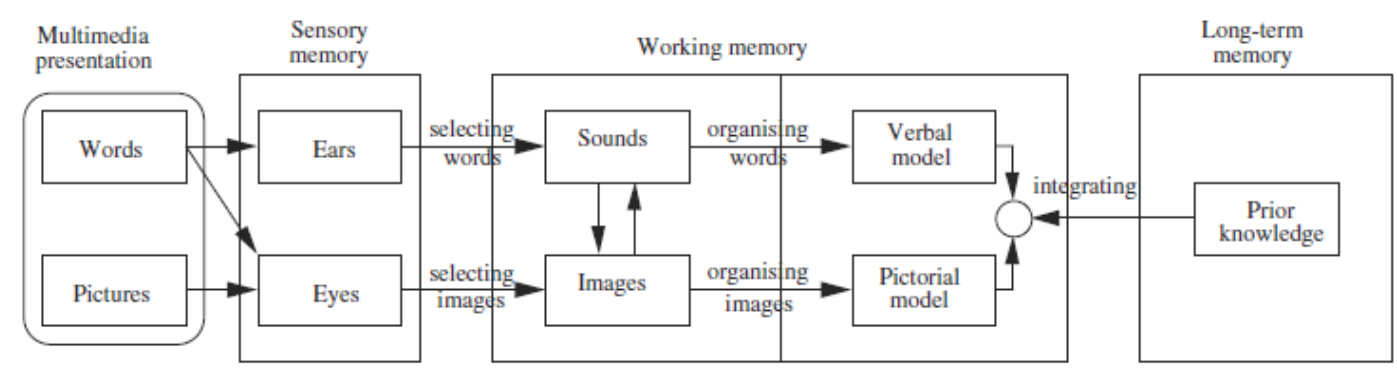

Figure 1: Cognitive theory of multimedia learning (Mayer, 2016, p.52).

\section{TPACK Framework}

Building on the notion of Pedagogical Content Knowledge (Shulman:1986), TPCK or TPACK is a dynamic construct that describes the knowledge teachers rely on when designing and implementing curriculum and instruction while guiding their students' thinking and learning with digital technologies in their specific content areas (Niess, 2015). TPACK is a rather young research field, which is still searching for a generally accepted and solid theoretical conceptualization (Angeli, Valanides: 2015), but is believed to be the basis of good teaching with technology. Moreover, Koehler \& Mishra (2009, p.66) emphasize that TPACK requires the following: an understanding of the representation of concepts using technologies; pedagogical techniques that use technologies in constructive ways to teach content; knowledge of what makes concepts difficult or easy to learn and how technology can help redress some of the problems that students face; knowledge of students' prior knowledge and theories of epistemology; and knowledge of how technologies can be used to build on existing knowledge and to develop new epistemologies or strengthen old ones. There are three components of teachers' knowledge which interdependently connected in this framework. They are: Content Knowledge (CK), Pedagogical Knowledge (PK), and Technological Knowledge (TK). When these bodies of knowledge intersect, the Pedagogical Content Knowledge (PCK), Technological Content Knowledge (TCK), Technological Pedagogical Knowledge (TPK), and Technological Pedagogical Content Knowledge (TPCK) arise. At this point, TPACK becomes effective as a result of multiple interactions among content, pedagogical, and technological knowledge, and it is different from the concept of all three knowledge when they stand alone or in their individual intersections. The bodies of knowledge and the intersections in TPACK framework is presented in figure 2 below:

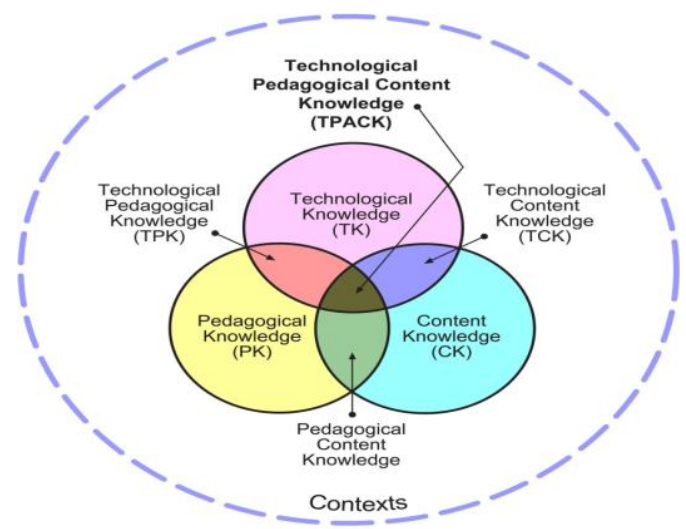

Figure 2: TPACK Framework (Kohler \& Mishra, 2009)

To understand TPACK framework, teachers should have a clear understanding of the terminologies of three domains of knowledge, Content Knowledge (CK), Pedagogical Knowledge (PK), Technological Knowledge (TK), and the four intersecting knowledge areas, Technological Content Knowledge (TCK), Technological Pedagogical Knowledge (TPK), Pedagogical Content Knowledge (PCK), and Technological Pedagogical Content Knowledge (TPACK). In an attempt to succinctly provide a definition of each construct, Chai, Koh and Tsai (2013) present definition and examples of TPACK dimensions as shown in the table below: 
TABLE 1:

DEFINITION AND EXAMPLES OF TPACK DIMENSIONS (CHAI, KOH AND TSAI, 2013, P.33)

\begin{tabular}{lll}
\hline $\begin{array}{l}\text { TPACK } \\
\text { Construct }\end{array}$ & Definition & Example \\
\hline TK & $\begin{array}{l}\text { Knowledge about how to use ICT hardware and software and } \\
\text { associated peripherals }\end{array}$ & $\begin{array}{l}\text { Knowledge about how to use Web 2.0 } \\
\text { tools (e.g., Wiki, Blogs, Facebook) }\end{array}$ \\
\hline PK & $\begin{array}{l}\text { Knowledge about the students' learning, instructional methods, } \\
\text { different educational theories, and learning assessment to teach } \\
\text { a subject matter without references towards content }\end{array}$ & $\begin{array}{l}\text { Knowledge about how to use problem- } \\
\text { based learning (PBL) in teaching }\end{array}$ \\
\hline CK & $\begin{array}{l}\text { Knowledge of the subject matter without consideration about } \\
\text { teaching the subject matter }\end{array}$ & $\begin{array}{l}\text { Knowledge about Science or } \\
\text { Mathematics subjects }\end{array}$ \\
\hline PCK & $\begin{array}{l}\text { Knowledge of representing content knowledge and adopting } \\
\text { pedagogical strategies to make the specific content/topic more } \\
\text { understandable for the learners }\end{array}$ & $\begin{array}{l}\text { Knowledge of using analogies to teach } \\
\text { electricity (see Shulman, 1986) }\end{array}$ \\
\hline TPK & $\begin{array}{l}\text { Knowledge of the existence and specifications of various } \\
\text { technologies to enable teaching approaches without reference } \\
\text { towards subject matter }\end{array}$ & $\begin{array}{l}\text { The notion of Webquest, KBC, using } \\
\text { ICT as cognitive tools, computer } \\
\text { supported collaborative learning }\end{array}$ \\
\hline TCK & $\begin{array}{l}\text { Knowledge about how to use technology to represent/research } \\
\text { and create the content in different ways without consideration } \\
\text { about teaching }\end{array}$ & $\begin{array}{l}\text { Knowledge about online dictionary, } \\
\text { SPSS, subject specific ICT tools e.g. } \\
\text { Geometer's Sketchpad, topic specific } \\
\text { simulation }\end{array}$ \\
\hline TPACK & $\begin{array}{l}\text { Knowledge of using various technologies to teach and/represent } \\
\text { and/ facilitate knowledge creation of specific subject content }\end{array}$ & $\begin{array}{l}\text { Knowledge about how to use Wiki as a } \\
\text { communication tool to enhance } \\
\text { collaborative learning in social science }\end{array}$ \\
\hline
\end{tabular}

Identical to problems Shulman recognized in the 1980s, technological knowledge has been considered to be separated from pedagogical and content knowledge. Many approaches to teachers' professional development offer a one size-fits-all approach to technology integration when, in fact, teachers operate in diverse contexts of teaching and learning (Koehler \& Mishra, 2009). As a framework for the design of teacher education programs, the TPACK framework addresses the problem arising from an overemphasis on technological knowledge in many ICT courses that are conducted in isolation from teachers' subject matter learning and pedagogical training (Chai, Koh, \& Tsai, 2013). Furthermore, in order to explain the types of ICT integration practices enacted in classroom, they suggest that the TPACK models may need to be expanded. In expanding TPACK, there is a valuable example work have been introduced by Jamani and Figg (2015) as TPACK-in-practice framework. In this framework, they identify practicebased characteristics and actions representing TPCK-in-practice, TCK-in-practice, and TPK-in-Practice. They believe that those specifics skills and knowledge can be explicitly taught in a variety of professional learning context to develop teacher knowledge of technology-enhanced teaching. The components of TPACK-in-practice are illustrated in the following table:

TABLE 2:

THE COMPONENTS TPACK-IN-PRACTICE (JAMANI \& FIGG 2015, P.142)

\begin{tabular}{l|l}
\hline TPCK-in-practice & $\begin{array}{l}\text { Knowledge about how to design technology-enhanced instructional experiences for different models of } \\
\text { teaching (e.g., Direct Instruction, Problem-based Learning, Inquiry-based Learning) to meet content } \\
\text { learning goals. }\end{array}$ \\
\hline TCK-in-practice & $\begin{array}{l}\text { Knowledge about content-appropriate technologies (knowledge of tools of a discipline and ability to } \\
\text { appropriately repurpose tools across disciplines) and teachers' ability to use the tool (personal attitudes, } \\
\text { skills, and comfort level with these technologies). }\end{array}$ \\
\hline TPK-in-Practice & $\begin{array}{l}\text { Knowledge of practical teaching competencies (use e.g., classroom management, differentiated support, } \\
\text { and assessment) to plan and implement technology enhanced lessons. }\end{array}$ \\
\hline
\end{tabular}

\section{METHOD}

This study employed qualitative research procedures and practices in which the researchers seek to understand a phenomenon by focusing on a total picture of how the subject of this study models his teaching and learning process based on the TPACK framework. The teacher educator is chosen as the subject of this study meets the criteria required. The subject of this study is an active lecturer in the English department who teaches technology courses and consistently integrates technology into his teaching and learning process using TPACK. Moreover, his educational background is in the field of technology. He obtained his Masters Degree in Leadership and Technology while his Doctorate degree is in Technology and Pedagogy. Furthermore, he has presented his paper at national and international conferences about technology integration in teaching and learning process.

In this study, a biographical case study narrative is used as Barkhuizen, Benson, and Chik (2014:9) state, "biographical case studies are studies of individuals, in which the researchers elicit data from the participant and write them up as narratives, possibly for further analysis". Then, Creswell (2012) points out that a narrative typically focuses on studying a single person, gathering data through the collection of stories, reporting individual experiences, and discussing the meaning of those experiences for the individual. The experience here is in line with Connelly and 
Clandinin's work, which is in turn based on Dewey's work on teacher knowledge as knowledge that is personal, practical, shaped by, and expressed in practice (Clandinin, 2013).

To support data collection process, interview and observation were used in this study. Face to face semi-structured interview data collection was employed and a mobile phone with good quality sound was used as an instrument to record the interviews. Barkhuizen, Benson, and Chik's (2104) opinion is adopted that in semi-structure interviews, researchers used an interview guide as the resource to direct the interview, but at the same time, the questions are open-ended to allow the subject of this study to elaborate and to pursue the developing theme that is the TPACK to encourage the subject of the study to describe his experiences in modeling TPACK framework. In addition to the interview process, the researchers also conducted observation to have more exploration on his model of teaching using TPACK framework. In doing the observations, the researchers use Jamani and Figg's framework of TPACK-in-practice that highlight TPK, TCK and the TPCK to distinguish the subset of specific actions within the TPACK knowledge domain in practice. The researchers observed the activities both in face-to-face classroom interactions and in the Facebook closed-group discussion technology platform. Based on the results of observations, the researchers also formulated questions for further interviews to explore and clarify important points or issues happened in the process of observations.

Describing and explaining all data that had been recorded, observed, and collected in the field were presented on the basis of the procedures suggested by Miles and Huberman (1984). The procedures included three flows of analysis: data reduction, data display, and data verification or conclusion drawing. In analyzing the data the researchers used inductive and deductive approaches (Patton, 2002). Through the deductive approach, the researchers brought a preliminary framework from the literature to interact with and analyze the data. To develop categories, themes, and patterns in the data, which arise from the interaction between the researchers and the data, the researchers applied inductive analysis.

\section{FINDINGS}

From the result of interviews, it is found that in modeling the TPACK framework, he involved as well as strengthened pre-service teachers' knowledge of technology integration during courses. He introduced the theory of TPACK framework, the intersections of Technological Content Knowledge (TCK), Technological Pedagogical Knowledge (TPK), and Technological Pedagogical Content Knowledge (TPACK) into practice during the teaching and learning process. Those intersections were created from the integration of three important knowledges: Technological Knowledge (TK) Content knowledge (CK) and Pedagogical knowledge (PK) for teachers. When he was asked about how to design his activities based on TPACK framework, he said that planning is important, and it would be more focused when a teacher could identify the benefits of a technology. Then, by looking at created lesson plan, he could determine whether the technology is suitable or not. Knowing the detail of a technology is critical. To him all kinds of technologies are rewarding. From literature he had read, technologies are divided into three types. First, traditional technology likes books or the use of the body in teaching. Second, modern technology marked by the use of electrical devices, and third, advanced technology that has been connected to the internet.

After carefully scrutinizing International Society for Technology in Education (ISTE) standards for teachers and students, he decided to use advanced technology for his teaching so that students of English department could be innovative designers. As he says:

And they can adopt all of them. But it is still in the domain of ISTE. They should be the creator, right? Designer. So I hope that I will develop their critical thinking, to construct, err, their critical thinking in constructivism, so they can operate any software they want. As long as in the frame of TPACK, right? (interview dated January 24, 2017).

Because the TPACK framework is still a theory, he felt that it is necessary for him to unpack this framework into details to make it more practical. To unpack this framework, he created his own model for teaching called PACI, later be revised to PACIFiC, as a combination of software and the use of the internet. He says, "First we have to give the model. So the most important is how to model. That's it." (interview dated September 6, 2016). Then he strengthens his argument on the importance of having a model for teaching and learning process.

Right? So it is the model. With God will, if we give the model properly, our students will adapt to our teaching model indirectly. Like people said - err not what people said, but according to what researchers have found that how we teach will affect how our pre-service teachers teach. (interview dated September 6, 2016).

To clarify the research subject's explanations on how he models teaching and learning based on the TPACK framework, further interviews and observations were carried out. Data from the interviews and observational guide based on Jamani and Figg's framework of TPACK-in-practice are used to explore his activities in every construct of TPACK within three intersections of knowledge areas. Findings on these three intersections namely Technology and Content (TCK-in-practice), Technology and Pedagogy (TPK-in-practice), and the Technology, Pedagogy, and Content (TPCK-in-practice) are presented below.

\section{A. The Intersection of Technology and Content (TCK-in-practice)}

The implication of his knowledge on technology integration is to make TPACK a valuable framework for teaching. He then realized that this framework should be chunked into details to make it more practical. He decided to make a model for implementing this framework. This model uses varieties of software namely PowerPoint (P), Audacity (A), Camtasia (C), and the use of the internet (I) called PACI Model. This was created through careful consideration because 
it has specific functions depending on the software used. PowerPoint is chosen as the base for the integration. Features exist in PowerPoint that are quite complete and easy to use. He says: "The first thing about PowerPoint because it can connect to anything, connect all of the hyperlinks into multimedia". (interview dated February 27, 2017). The second software is Audacity. It is a simple kind of software to edit sounds. It can be used to edit, to trim which part of audio should be deleted or still be used. The next software is Camtasia. Camtasia has been extensively used to record all things happening on the screen, monitor or laptop by world researchers to check students' theses. This software made everything on the screen recordable. Furthermore, it is user-friendly and has many functions. The use of the Internet is important in this model because it is the source of everything like animations, fonts, and others and it can be used for sources of learning. When all this software combined, they would be standalone results that create English language multimedia. After using PACI model for a year, he developed a new model he called PACIFiC by adding two new software, Filmora, and Cmap tool. Filmora can be used for editing video and Cmap for seeing how students think in the form of concept map as well as for building students' critical thinking. In an interview he explains the reasons for adding new software in his model:

PACI is.. err PACIFiC is err the development of PACI. So after I evaluated the suggestions from students, the Power Point, Audacity, Camtasia, and Internet have no video yet. So in PACIFiC, I add element of video because in EFL teaching, video will be very helpful. That was what I read from several articles. So I have to add video in PACI framework. So I have to decide what kind of editing software for video. After exploring some sources, I decided to use Filmora. So Filmora is the editing software for video. Thus, in PACIFiC students can create video by themselves, regarding to the material they will deliver. So they have to make this video by their own mobile phone or other recorders and then edit it in Filmora. After that they will combine it with PACI. So PACI is actually err not perfect yet, and the existence of video would complete it. With this new PACIFiC model, Power Point, Audacity, Camtasia, internet, Filmora and Cmap, I think that they all can be combined in a teaching process. It means that the supplemental technology in my teaching is already completed. (interview dated October 24, 2016)

In the implementation of technological content knowledge (TCK), he gave an example of how technological knowledge such as how to use software is transformed by the application of technology. Pre-service teachers at this point are encouraged to learn all software in the PACIFiC model by themselves, individually and within groups through links provided. Here students automatically developed their technological knowledge (TK) during the learning process because he assigned them to create content in English like grammar and text genres to develop their content knowledge (CK) using the PACIFiC model they had already learned. In this context, he models for the pre-service teacher involvement in the activity of how technology and content knowledge are closely related and intersected (TCK). The activities in the intersection of TCK are presented in the table 3.

TABLE 3:

MODELING TPACK IN THE INTERSECTION OF TECHNOLOGY AND CONTENT (TCK-IN-PRACTICE)

\begin{tabular}{|l|l|l|}
\hline Components of TPACK - in - practice & Characteristics of components & Activities \\
\hline $\begin{array}{l}\text { Technological Content Knowledge (TCK-in- } \\
\text { practice) }\end{array}$ & $\begin{array}{l}\text { a. Knowledge of content - } \\
\text { appropriate technologies. } \\
\text { b. Competencies with content } \\
\text { appropriate technologies. }\end{array}$ & $\begin{array}{l}\text { a. The research subject identified varieties of software in } \\
\text { exploiting the benefits of technology based on their functions } \\
\text { for teaching and learning. } \\
\text { b. He created PACI model then repurposed it to PACIFIC } \\
\text { model for pre-service teachers to create English language } \\
\text { learning multimedia with the topic of grammar and text genres. }\end{array}$ \\
\hline
\end{tabular}

\section{B. The Intersection of Technology and Pedagogy (TPK-in-practice)}

After preparing models for the TPACK framework and the contents required to be integrated into teaching and learning process, the subject of this study then implemented the intersection of Technological knowledge (TK) and Pedagogical knowledge (PK), that is Technological pedagogical knowledge (TPK) to be the form of experiential learning for pre-service teachers. At the first point of technology and pedagogy intersection, he made plan for assessment, activity choice, sequencing in the implementation, differentiation for technical competence and backup instructions.

In the planning stage, he prepared assessments form for measuring students' process in accomplishing English language multimedia and the assessment for the final products created by students. However, he said that he put more focus on the process rather than the products created by students. He explains:

I prefer to see the process of learning. So in the teaching-learning for example, it is as if we make a product, right? These products have final results. I usually see the ability of my students during. I do not always see the products results. The thing that I consider is their process of how they make it. This process will be shown when, first, because in the process of the project, they have to..err. what is it... mm.. show us in front of the class, this is their progress. Then I usually ask them how to make it. So I see the process. (interview dated September 6, 2016)

When the researchers insisted on finding out whether any specific assessments such as a rating scale was applied to the evaluation of process or the products, he replied that he designed his own rubric for them. The rubric he made was based on students' process of creating multimedia; for example, editing process in power point.

For example, a project contains PowerPoint animation, and that animation is synchronized well with the voice. Then the rubric will be err... the ability in editing of voice and image synchronization. So from that rubric, their process can 
be seen. If they follow this process the product will be good. Then when we see the product, we'll determine it as good. So the rubric is their reference to create the good product. (interview dated September 6, 2016)

He further replies that the pre-service teachers' assignment is to create English language multimedia therefore he encouraged them to learn and discuss Mayer's twelve principles of Multimedia Learning for the standard of their creation. Next, he chose some activities matched to the implementation of the TPACK framework for technology integration. As he believes that pre-service teachers should experience 'how to learn and how to teach' activities in their learning process of English language teacher education, he changed the activities and the content subject of computer courses to fit this objective. He said that technology courses in higher education have been criticized because the focus is on how to operate the technology, or on a techno-centric approach. It seems that teacher educators and pre-service teachers did not know how actually to implement technology into their teaching to make content easy to deliver or to make content understandable or teachable. To address this issue, he preferred to use blended learning methods involving face-to-face instruction in the classroom and Facebook closed-group discussion as the technology platform. He explained that the use of Facebook would help him to implement a flipped-classroom for the effectiveness and efficiency of his classroom activities. It would then create the basic implementation for student-centered learning in his classroom.

Right? I have to change my teaching method. And in this case I have done TPACK in my teaching. So I accommodate Facebook closed-group discussion. Okay, all of students in those classes should be connected with Facebook. What is the function of this media? It's for err. sharing.. yes, sharing. All of the data related the way how you operate the specific software for example PowerPoint, Audacity, Camtasia. All of them. I will upload something here first, this is the way you create something in Camtasia, here's the link. Okay, and I make instruction and all of the students have to share other useful links. So all of students will upload the tutorial of Audacity.. or Camtasia, etc. So the discussion is not only in the classroom but also in sharing groups. Oh yeah, in those sharing group at Facebook, I apply Flipped Classroom. (interview dated January 24, 2017)

In his courses, the Facebook closed-group discussion is used as a flipped-classroom to give pre-service teachers knowledge and skills prior to attending the face-to-face sessions. Contents provided are ebooks like how to teach English skills, or documents and books based on Curriculum 2013 applied in Indonesia, links, tutorials on technological skills and so on, provided both by the teacher educator and pre-service teachers. Besides providing contents for learning, pre-service teachers also used this platform for submitting their completed assignments.

As he implemented this blended learning method, he also conducted face-to-face interaction in the classroom for clarifying theories and practice on technology integration and checking the process of creating English language multimedia. When pre-service teachers presented their works as part of the process in accomplishing their English language multimedia in the classroom, he usually asks others to make comments as part of peer assessment activity. After they gave comments, he clarified some important points that he thought would help students to improve the quality of their English language multimedia. The process of multimedia refinement happened during face-to-face interaction.

Remember. The video is only to make the explanation clearer to be understood. Okay, do you understand? So it is explanation, video, activities, explanation again. For activity 1 for example, focus on listening, activity 2 for reading, and the last is writing, you get it? (classroom observation, dated September 26, 2006)

By changing the teaching method and implemented it in sequence using PACIFiC, pre-service teachers gradually see, learn, observe, and experience the way of 'how to learn and how to teach' English using technology. Both he and the pre-service teachers got mutual benefits in the process of creating English language multimedia products. He could learn many things from them as in some cases the pre-service teachers have more skills in technological knowledge (TK); conversely, they gained knowledge on how to manipulate technology for teaching English through online and face-to-face discussion in refining the products of multimedia they have created. They directly incorporated a variety of technological activities such as the use of various software in PACIFiC, browsing activities for specific books or articles, downloading Youtube video, fonts, sounds, background, templates, animation GIFs for power point, and the effective use of Facebook-closed group discussion for learning. Technology skills are built and developed by requiring pre-service teachers to work individually and collaboratively on selecting software and using links that both students and teacher provide.

The method he chose for the teaching-learning process was intended to develop pre-service teachers' critical thinking by providing tasks and assignments which carried out based on project-based learning. They were given more opportunities to participate actively in their tasks by experiencing trial and error, learning by doing and these are the characteristics of student-centered learning. Even though he gave more opportunities for them to participate, he introduces the basic technical skills related to designing a slide included how to create a slide, added and formatted text on the slide, added and manipulated images on the slide, and added a background to the slide. Helping pre-service teachers to implement those skills would help pre-service teachers to create language learning multimedia. Besides having the differentiation for technical competence, he also planned a backup instruction for alternate technologies by assigning pre-service teachers to provide different software resemble to PACIFiC that later could be developed into a new model. 
To help him in implementing technology practice in the intersection of technology and pedagogy, he provided digital classroom resources by providing internet access and computer with latest equipment specification in computer laboratory and campus surrounding funded by the faculty leader. After everything has been set up in planning and preparation stage, he modeled technology across applications integrated in PACIFiC by involving pre-service teachers in groups and personal project to implement the technology to enhance English language learning such as grammar and text genres. He managed his technology classes by having learning contract with pre-service teachers and by using Facebook closed-group discussion and face-to-face classroom interaction (blended learning and flipped classroom). Table 4 below is presented to show how the research subject models TPACK in the intersection of TPK.

TABLE 4:

MODELING TPACK IN THE INTERSECTION OF TECHNOLOGY AND PEDAGOGY (TPK-IN-PRACTICE)

\begin{tabular}{|c|c|c|}
\hline $\begin{array}{l}\text { Components of } \\
\text { TPACK - in - } \\
\text { practice }\end{array}$ & Characteristics of components & Activities \\
\hline $\begin{array}{l}\text { Technological } \\
\text { Pedagogical } \\
\text { Knowledge } \\
\text { (TPK-in- } \\
\text { practice) }\end{array}$ & $\begin{array}{l}\text { a. Planning: } \\
\text { - Assessment } \\
\text { - Activity choice } \\
\text { - Sequencing } \\
\text { - Differentiation for technical } \\
\text { competence } \\
\text { - Backup instruction } \\
\text { b. Preparation: } \\
\text { - Technology practice. } \\
\text { - Digital classroom resources for teacher } \\
\text { and students use. } \\
\text { c. Implementation: } \\
\text { - Modeling tech use to and for students. } \\
\text { - Classroom management. }\end{array}$ & $\begin{array}{l}\text { a. Planning } \\
\text { - The research subject matched assessment to tech-enhanced learning activities } \\
\text { using TPACK framework and created assessment rubric based on the principles of } \\
\text { Mayers' Cognitive Theory of Multimedia. } \\
\text { - He chose a Project-based learning (PBL) model of teaching, chose blended- } \\
\text { learning method, Flipped classroom approach, and combination of technological } \\
\text { tools named PACIFiC for teaching-learning activity. } \\
\text { - He planned to build and develop pre-service teachers' TPACK through the } \\
\text { experience of using the PACIFiC in sequence to create language learning } \\
\text { multimedia. } \\
\text { - He planned to differentiate technical competence by introducing the basic } \\
\text { technical skills related to designing a slide included how to create a slide, added and } \\
\text { formatted text on the slide, added and manipulated images on the slide, and added a } \\
\text { background to the slide. Implementing those skills would help pre-service teachers } \\
\text { to create language learning multimedia. } \\
\text { - He planned a backup instruction for alternate technologies by assigning pre- } \\
\text { service teachers to provide different software resemble to PACIFiC that later could } \\
\text { be developed into a new model. } \\
\text { b. Preparation. } \\
\text { For technology practice, he provided digital classroom resources by providing } \\
\text { internet access and computer with latest equipment specification in computer } \\
\text { laboratory and campus surrounding funded by the Faculty Leader. } \\
\text { c. Implementation } \\
\text { - He modeled technology across applications integrated in PACIFiC by involving } \\
\text { pre-service teachers in groups and personal project to implement the technology to } \\
\text { enhance English language learning such as grammar and text genres. } \\
\text { - He managed his technology classes by having learning contract with pre-service } \\
\text { teachers and by using Facebook closed-group discussion and face-to-face classroom } \\
\text { interaction (blended learning and flipped classroom) }\end{array}$ \\
\hline
\end{tabular}

\section{The Intersection of Technology, Pedagogy and Content (TPCK-in-practice)}

As he has developed PACI into the PACIFiC model to help students create English language multimedia, the subject of this study managed to promote the shift from techno-centric pedagogy where he used to teach skills on using technology to a content-centric pedagogy in which he developed students' understandings about teaching content with technology. The model he developed, a careful selection of blended learning method, and project-based learning with specific content of English, was his effort to introduce and at the same time model the implementation of the TPACK framework for pre-service teachers in the English Department of Mulawarman University. Step-by-step implementation was achieved for content and activities through his technology courses named Computer Literacy (CL), Computer Application (CA), and Computer Assisted Language Learning (CALL) which have all emphasized the importance of acknowledging TPACK as a valuable framework for producing English Language multimedia for teaching-learning English. In incorporating all dimensions of TPACK, he assigns pre-service teachers to create English language multimedia that are expected to provide experiences in technology integration and to be used for other courses related to teaching.

So when I give them assignment, group or individual assignment to teach recount text for example, it means that they have to involve the four skills in the recount text; listening, reading, speaking, and writing. So the students will choose which one will be the focus. If they choose reading as the focus, then they have to create multimedia. How they make it to create the easier teaching for them and more importantly to create easier learning for their students in recount text. So the focus is how they make media to be used in teaching. In TEFL we will see how they apply it. (interview dated September 6, 2016)

To implement all dimensions of TPACK in his classess, he firstly discussed learning contracts that he has already planned and introduced project based learning, topics covered during the semester, its goals, and its projects. Then he asked the chairman of the class to administer a Facebook closed-group discussion for the class. After that, he started to upload and shared learning materials, theories, links, asked pre-service teachers to learn PACIFiC and how to operate 
various software used in the model. Then he assigned them to create the English language multimedia and the process of accomplishing the assignment was done through discussion, presentation, evaluation and refinement activities both in Facebook closed-group discussion and face-to-face interactions. Activities carried out in the whole process of teaching and learning have introduced pre-service teacher to seeing, learning, and observing the complex process of integrated teaching and learning which guide them to experience 'how to learn and how to teach' through a student-centered learning approach. The feature of how the research subject models TPACK in the intersection of TPCK is presented in the following table.

TABLE 5:

MODELING TPACK IN THE INTERSECTION OF TECHNOLOGICAL PEDAGOGICAL CONTENT KNOWLEDGE (TPCK -IN-PRACTICE)

\begin{tabular}{|l|l|l|}
\hline $\begin{array}{l}\text { Components of } \\
\text { TPACK - in - } \\
\text { practice }\end{array}$ & Characteristics of components & Activities \\
\hline $\begin{array}{l}\text { Pechnological } \\
\text { Content }\end{array}$ & $\begin{array}{l}\text { a. Repertoire of tech-enhanced activity } \\
\text { types representing content knowledge. } \\
\text { Knowledge } \\
\text { (TPCK-in- Knowledge of content - based models } \\
\text { of teaching appropriate }\end{array}$ & $\begin{array}{l}\text { a. He has the ability to analyze the structure of technology and found that there } \\
\text { are some technological tools could enhance learning when they are used together } \\
\text { to create English language multimedia. He selected and used them as model to be } \\
\text { implemented in his technology classroom and managed to shift the activity type } \\
\text { from a techno-centric pedagogy to content-centric pedagogy. } \\
\text { b. He has analyzed types of knowledge to be learned for the pre-service teachers } \\
\text { and made the pre-service teachers easier to understand the TPACK and all its' } \\
\text { intersections by selecting appropriate model of teaching for technology-enhanced } \\
\text { instruction that is students-centered learning through Project based learning, } \\
\text { blended learning, flipped classroom and the PACIFiC. }\end{array}$ \\
\hline
\end{tabular}

\section{DISCUSSION}

This study aimed to explore how the teacher educator models his teaching and learning based on the TPACK framework in his technology course. This study reveals some findings related to how he models the TPACK framework. First, the teacher educator as the subject of this study obviously applied a kind of New Technology (Cuban, 2001) or Digital Technology (Koehler \& Mishra, 2009) in his technology courses. He managed to combine varieties of software connected to the use of internet called PACIFiC as abbreviations of PowerPoint (P), Audacity (A), Camtasia (C), Internet (I), Filmora (Fi), and Cmap-tool (C) to model the TPACK framework for pre-service teachers to create English language multimedia as a product of offline-based language teaching-learning. His capability in manipulating and combining varieties of presentation tool, sound-editing, screen recording, video-editing, and concept-mapping software, into one package to create English learning multimedia is the representation of his understanding of the TPACK framework. It is supported by Kramarski and Michalsky's (2015) viewpoint that the use of technology tools means more than having access to the tool and learning the technical skills to handle it, and the decisions of selecting the technology tools should consider significant added value to teaching with technology that enables student-centered learning.

Second, he applied Project-based learning (PBL) that supports a student-centered learning approach to create Language learning multimedia as the product. It is found that there are potential benefits regarding the implementation of PBL as an instructional model. Grant (2009) presents some research findings which state that project-based learning would receive emphasis over memorization of broad content knowledge; learner motivation to complete projects is heightened when projects are personally relevant; PBL offers learners opportunities to guide, manage and monitor their learning through self-direction and self-regulation; PBL integrates collaboration and cooperation meaningfully when student teams remain intact throughout a project or individuals use peer reviews and more informal social negotiations; PBL provides a variety of resources, tools and scaffolds; and finally, some project-based learning lessons make use of reflection. He prefers student-centered rather than teacher-centered learning to provide pre-service teachers with experiences to foster their critical thinking, and build learners'autonomy, creativity and innovation. By doing so, the learners no longer play the role of passive recipients of information, but of active participants in the process of developing their own expertise through selecting, deconstructing, building and creating knowledge and new meanings together with their interlocutors (Laakkonen, 2011).

Third, In carrying out PBL, he applied a flipped classroom approach by using social media in the form of Facebook. There is a discussion feature in it and he asked the chairman of the class to create closed-group discussion. In this group he provides pre-service teachers with knowledge and skills prior to attending the face-to-face sessions related to the project assigned to the class. In addition, pre-service teachers can also submit their works and for him it functioned as ongoing assessment to see the prosses of acomplishing the multimedia project. At this point, It is an appropriate way to incorporate flipped classroom with a project-based learning as Ramazani, Graney, Marshall, and Sabieh (2016) explain that there are two opportunities created by establishing a flipped learning approach for English learners. One of the opportunities is the ability to incorporate project-based learning in a flipped classroom as illustrated in an intermediate to high-intermediate level intensive English program class at Saint Michael's College (Vermont, United States).

By looking at those findings, it is understood that in implementing TPACK framework the teacher educator as the subject of this study incorporates a model of learning that is Project Based Learning (PBL). The final product expected 
from the framework is an English Language multimedia materials. To create this multimedia product, new technology or digital tools are needed. With the TPACK framework in mind, he understood that there is a unique combination of technology, pedagogy, and content within every teacher, course, or every view of teaching, and therefore there will be no single technological solution best applied (Koehler \& Mishra, 2009). Furthermore, Koehler and Mishra fully describe the idea of TPACK into a situated form of knowledge, acknowledging that significant achievement in technology integration insists on teachers' understanding of the interconected relationships between content, pedagogy, technology, and knowledge of the surrounding educational context, including knowledge about students, the school, the infrastructure available, and the environment.

The solution in manipulating context or a situated form of knowledge therefore lies in the ability of the teacher educator and in this study, it is found that he decided to combine varieties of software he named PACIFiC. This is a creative invention from the teacher educator to contextualize TPACK using PBL with the PACIFiC, and in the process of acomplishing the project as well as developing pre-service teacher knowledge of TPACK, he incorporated the flipped classroom approach so the pre-service teachers could directly see, learn, observe, and experience how to learn and how to teach English using technology.

It impressed the researchers that this kind of modeling TPACK, inspired by, or if not, coincidently resembling TPACK-in-Practice, can be described as knowledge about how to design technology-enhanced instructional experiences for different models of teaching to meet content learning goals (Jamani \& Figg, 2015). PACIFiC here is the creative product or could be a prototype of model of technology tools creation of the teacher educator in navigating the space defined by the three elements of content, pedagogy, and technology and the complex interactions among these elements in specific contexts (Koehler \& Mishra, 2009). The way he models his teaching and learning based on the TPACK framework in his technology courses has shown that he had managed to contextualize TPACK using PBL with PACIFiC. With this model he managed to transform TPACK into an actionable form of teaching in the technology classroom.

\section{CONCluding REMARKS}

In answering question about how teachers can integrate technology into their teaching, Koehler and Mishra (2009:62) explain, "An approach is needed that treats teaching as an interaction between what teachers know and how they apply what they know in the unique circumstances or contexts within their classrooms. There is no 'one best way' to integrate technology into the curriculum. Rather, integration efforts should be creatively designed or structured for particular subject matter ideas in specific classroom contexts." The findings of this study show that the teacher educator's understanding of TPACK has made him model his teaching-learning process on what the researchers call a Contextualized TPACK using PBL with the PACIFiC. His creative idea lies in the creation of a combination of various software he labels PACIFiC to create English language multimedia that can be used for either teaching or learning media. PACIFiC identifies software instruments that were carefully selected based on their specific functions and which worked well to create the multimedia. Moreover, multimedia products created using PACIFiC in his technology courses were offline-based, which can be useful in a low-tech environment where online learning is somewhat restricted. This study is a work example that can be used for further research to address one of Chai, Koh and Tsai's (2013) findings that educators notice a strong need for the sharing of resources, examples, best practices and for further studies of ICT integration.

\section{ACKNOWLEDGEMENTS}

Our appreciation is extended to Dr. Derek Wallace from Victoria University of Wellington, NZ, for his willingnes to do a basic proof-read for improving grammar and sentence construction of this manuscript. This manuscript is dedicated with respect to our research member, Prof. Dr. Arifuddin Hamra who has passed away before the finalization process of the study.

\section{REFERENCES}

[1] Angeli, Charoula, Valanides, Nicos. (2015). Technological Pedagogical Content Knowledge: Exploring, Developing, and Assessing TPACK. New York: Springer.

[2] Barkhuizen G, Benson P, Chik A. (2014). Narrative Inquiry in Language Teaching and Learning Research. New York: Routledge.

[3] Bax, Stephen. (2003). CALL - Past, Present, and Future. Elsevier Science Ltd. System 31, p.13-28.

[4] Chai, C.-S., Koh, J. H.-L., \& Tsai, C.-C. (2013). A Review of Technological Pedagogical Content Knowledge. Educational Technology \& Society, 16 (2), p.31-51.

[5] Clandinin, J.D. (2013). Engaging in Narrative Inquiry. New York: Left Coast Press, Incorporated.

[6] Creswell, J.W. (2012). Educational Research: Planning, Conducting, and Evaluating Quantitative and Qualitative Research. Boston: Pearson.

[7] Cuban, Larry. (2001). Oversold and Underused Computers in the Classroom. London. Harvard University Press.

[8] Davies, Chris. (2007). What Can Technology do for/to English? In Anthony Adams, A., Brindley, S. (eds.), Teaching Secondary English With ICT. England. Open University Press, McGraw-Hill Education, p.50-66. 
[9] Goktas, Yuksel, Yildirim, Zahide, Yildirim, Soner. (2008). A review of ICT Related Courses in Pre-service Teacher Education. Pasific Education Review vol. 9(2), p.168-179.

[10] Grant, Michael M. (2009). Understanding Projects in Project-based Learning: A Student's Perspective. American Educational Research Association. San Diego, CA.

[11] Jamani, kamini J. and Figg, Candace. (2015). The framework of TPACK-in-practice: designing content-centric technology professional learning context to develop teacher knowledge of technology-enhanced teaching (TPACK). In Angeli, Charoula, and Valanides, Nicos. Technological Pedagogical Content Knowledge: Exploring, Developing, and Assessing TPACK. New York: Springer, p.137-164.

[12] Kramarski, Bracha, and Michalski, Tova. (2015). Effect of a TPACK-SRL model on teachers' pedagogical beliefs, selfefficacy, and technology-based lesson design. In Angeli, Charoula, and Valanides, Nicos. Technological Pedagogical Content Knowledge: Exploring, Developing, and Assessing TPACK. New York: Springer, 89 -114.

[13] Koehler, M. J., \& Mishra, P. (2009). What is technological pedagogical content knowledge? Contemporary Issues in Technology and Teacher Education, 9(1), p.60-70.

[14] Laakkonen, I. (2011). Personal learning environments in higher education language courses: an informal and learner-centered approach. In S. Thouësny \& L. Bradley (Eds.), Second language teaching and learning with technology: views of emergent researchers. Dublin: Research-publishing.net, p.9-28.

[15] Mayer E., Richard. (2016). Introduction to Multimedia Learning. In Richard E. Mayer (ed.), The Cambridge Handbook of Multimedia Learning. Second Edition. Cambridge UK. Cambridge University Press, p.1-24.

[16] Miles, M. B. and Huberman, A. M. (1984). Qualitative Data Analysis. London: Sage Publication.

[17] Morrison, G.R., \& Lowther D. L. (2010). Integrating Computer Technology into the Classroom: Skills for the 21st Century. (Vol. 4). Boston New York: Pearson Education, Inc.

[18] Niess, Margaret L. (2015). Transforming Teachers' Knowledge: Learning Trajectories for Advancing Teacher Education for Teaching with Technology. In Angeli, Charoula, and Valanides, Nicos. Technological Pedagogical Content Knowledge: Exploring, Developing, and Assessing TPACK. New York: Springer, p.19-40.

[19] Patton, Quinn Michael. (2002). Qualitative Research \& Evaluation Methods.3 ${ }^{\text {rd }}$ Edition. London: Sage Publications.

[20] Ramazani B, Christine, Graney M., John, Marshall W., Helaine, Sabieh, Christine. (2016). Flipped Learning in TESOL: Definitions, Approaches, and Implementation. Tesol Jurnal 7.2, June 2016. TESOL International Association, p. 429-437

[21] Reinders, Hayo. (2009). Technology and second language teacher education. In Anne Burns and Jack C. Richards (eds.), The Cambridge guide to second language teacher education. Cambridge: Cambridge University Press, p.230-237.

[22] Rice, P. Marilyn, Johnson D, Ezzel B, Pierczynski-W, Michelle. (2008). Preservice Teachers' Guide for Learner-Centered Technology Integration into Instruction. Interactive Technology and Smart Education vol. 5, no.2. Emerald Group Publishing, p 103-112.

[23] Shulman S. Lee. (1986). Those who understand: knowledge growth in teaching. Educational Researcher, vol. 15(2), p 4-14.

[24] Warschauer, Mark, Healey, Deborah. (1998). Computers and Language Learning: Overview. Lang. Teach. 31, p. 57-71. United Kingdom, Cambridge University Press.

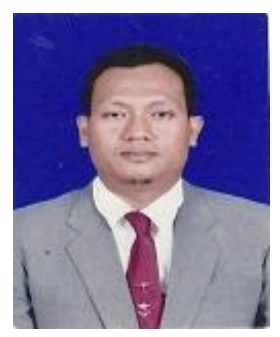

Iwan Setiawan is a lecturer at the English Language Education Department of Mulawarman University, Indonesia. He obtained his master's degree in Language and Literature from the State University of Surabaya, Indonesia, and is currently pursuing his doctorate program in English Language Education at the State University of Makassar. His research interest is in English language teaching and teacher education program.

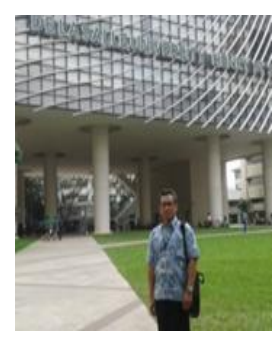

Arifuddin Hamra is a professor at the State University of Makassar. He completed doctorate degrees in the field of Reading in EFL Context at the Hasanuddin University, Makassar. He has been teaching English more than 35 years at teacher training college. 


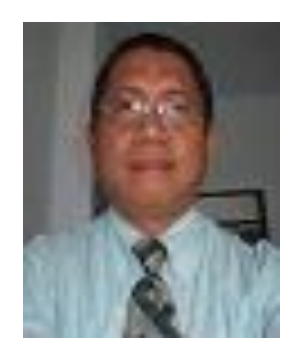

Baso Jabu is a professor of Applied Linguistics and has been teaching English as a Foreign Language at Universitas Negeri Makassar for more than 20 years. He got his Ph.D from the Hasanuddin University in Makassar, Indonesia in 2007. He was awarded a Specialist Certificate in Language Testing at the Regional Language Centre Singapore in 1996. Currently he is a member of TEFLIN (Teaching English as a Foreign Language in Indonesia) and MLI (Indonesia Linguistics Society). His main interest of research are TEFL and Language Assessment.

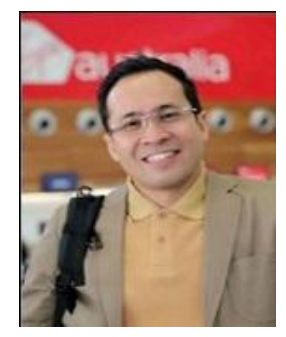

Susilo is a professor of ELT in the Faculty of Teacher Training and Education, Mulawarman University. He got his Ph.D from the State University of Malang in 2004. In 2007, he got Fulbright Senior Research Grant in CUNY, USA. His main interest of research are in ELT in remote regions of Indonesia, Discourse analysis, Constrastive rhetoric, and Postmodern. 